\title{
The Psychoanalysis of the Main Character in Handling Conflicts in Chernobyl TV Series
}

\author{
I Gusti Agung Ayu Ningrat Mayura Putri ${ }^{1)}$, I Gusti Agung Istri Aryani' ${ }^{2)}$ Ni Ketut Widhiarcani Matradewi ${ }^{3)}$ \\ ${ }^{1}$ Udayana University \\ ningratmayura@gmail.com \\ ${ }^{2}$ Udayana University \\ istri_aryani@unud.ac.id \\ ${ }^{3}$ Udayana University \\ ketut.widhiarcani@unud.ac.id
}

Received: $18^{\text {th }}$ June 2021| Revised: $28^{\text {th }}$ June 2021| Accepted: $2^{\text {nd }}$ July 2021

Email Correspondence: ningratmayura@gmail.com

\begin{abstract}
This study is aimed to describe the psychological aspects of the main character in handling the conflict the main character experienced in the story. The data for this study was taken from a TV Series entitled Chernobyl and collected by using observation technique and note taking technique. The collected data were analyzed by using qualitative method. There are two theories applied in this study. The first theory is the theory proposed by Kenney (1966) about conflict that divided into internal conflict and external conflict. The second theory is the theory proposed by Freud (1923) about psychoanalysis that divide human's psychological aspect into three; id, ego, and superego. The result of the analysis showed that the main character mainly encountered external conflicts because he had many different opinions with other characters. Afterward, the id, ego, and superego are used in handling the conflicts he experienced.
\end{abstract}

Keywords: psychoanalysis, main character, conflict, Chernobyl

\section{INTRODUCTION}

The concept of literature refers to the creative imagination of work through drama, novel, and poetry which are included in fiction, also autobiography, biography, and memoir which are included in nonfiction. These kinds of literary work correlates with what happened in society. Drama is as part of fiction categories in literature comes from a written work and modified into a play that is supposed to be performed into stages of dialogues. Drama also has elements to build up the story, namely intrinsic and extrinsic. In the intrinsic element of a drama, there is conflict, and it is considered to be important because it supports the storyline and make the story interesting to the readers. In general, conflict causes the

Online at https://journal.universitasbumigora.ac.id/index.php/humanitatis/

DOI : https://doi.org/10.30812/humanitatis.v8i1.1284 
readers to experience the tension of the story, make them keep on reading and feeling excited towards the story. Conflict that happens in a drama is in relation with the existence of a character because the character's role can develop the story more complex and resulting of some conflicts will be occurred. The role of a character is important because character indicates to perform the action of a story and make the plot line moving forward. Showing off the characters' motive or behavior will be able to assist the reader to grasp the psychological deeds of the character. Psychology as the study of human activities that involve thoughts and its behaviors is analyzed in order to identify the way humans feel their emotions such as sadness, happiness, satisfaction, guilt, etc., and how they operate their speculation, analysis, prediction, etc. that run in their mind. Therefore, it is important to understand the psychological aspects of a character in a story while also comprehending its character's attitudes and behavior especially in real life. In this study, psychoanalysis is applied to discover the psychological aspect of a character and how this aspect is used in managing conflicts that the character's currently experiencing.

The psychological aspects of a character that related to the conflicts occurred in the story are shown in a TV series called Chernobyl. Valery Legasov's behavior as the main character is affected by his psychological aspect seen from how he deals with the conflict. Therefore, this study is conducted to analyze the psychological aspect of the main character named Valery Legasov in order to get a broad knowledge of psychological mechanisms in a person. This study also can help others understand how to control and manage their mind and act according to Legasov's character in relation with his psychological aspects. Then, discussion is narrowed by analyzing the kinds of conflict experienced by the main character using the theory of conflict proposed by Kenney (1966) which is divided into internal conflict and external conflict. Furthermore, how the conflicts are handled based on the main character's psychological aspect are analyzed by using the theory of psychoanalysis proposed by Freud (1923) about three parts of human personality called tripartite; the id, ego, and superego. The minds and behavior that the main character possesses are in correlation with how the main character would handle the conflicts he experienced.

Conflict is a communication relationship which comes out naturally but it is defined as disagreement between individuals who have differing opinions or thoughts. Conflicts also have goals where two sides are being competitive against each other in order to achieve something. In a drama, conflict is an important element because it creates plots and it also can spice up the tension which can make the audiences interested and excited about the story delivered. The conflict can be in the form of a struggle of solving the problem, a fight with enemies, or even attempting to change the world. According to Kenney (1966), A conflict itself can be happened within the man thoughts. It belongs to internal conflict. This

Online at https://journal.universitasbumigora.ac.id/index.php/humanitatis/

DOI : https://doi.org/10.30812/humanitatis.v8i1.1284 
form of internal conflict occurred inside the character's mind, dealing with the decision-making issue, or clash between needs and beliefs. Kenney (1966: 13) also stated that, "Conflict is closely related to the elements of instability," therefore, internal conflict generally occurs within oneself because there is a struggle happening inside the human's mind. It is when a certain character has a decision-making issue and this happens during the time when a character encounters hesitation in settling a decision. Internal conflict can be also regarded as man versus self. Meanwhile conflict that happened between two men or more, conflict between society, and conflict between natures belong to external conflict. External conflict is a conflict which occurred outside of the characters. The struggles may happen because of the disagreement between characters, society, or nature. The form of conflicts can appear through physical conflict and social conflict. The external forces from outside of the character are getting in the way of the character's motive and resulted in having tension between other characters, society, or nature.

Thereafter, the conflicts experienced by the main character are handled using the theory of psychoanalysis by Freud (1923). According to him, human has psychological aspects called tripartite. They are; the id, ego and superego. Each one of them develops in different stages within human lives which affect the mind and also create behaviors to the human personality.

a. The Id, it is a component of human personality which includes instinct and some basic elements of humankind like being selfish or needy. According to Freud (1923), the id operates based on the pleasure principle, a principle which all your needs should be fulfilled immediately. The id holds the impulsive and unconscious part of the human mind, and to seek what the mind is looking for in order to get the immediate satisfaction.

b. The ego is the executor of the id and makes sure the id is in check according to reality principle. The reality principle lies in the external world, which ego operates the decision and to face the consequences. It is the way people seek for rational and realistic attempts to accomplish their needs in an acceptable manner in which it becomes a decision-making. The ego as the conscious part of human personality that mediates between id and superego.

c. The superego is considered as the conscious behavior of the mind that can distinguish between which one is right or wrong. The superego goes on with the moral values and to follow rules when the decision is being made. It is in order to prevent id, from causing damage. Even though superego lies with moral perfection and being ideal, superego cannot consider it in a realistic way.

Online at https://journal.universitasbumigora.ac.id/index.php/humanitatis/

DOI : https://doi.org/10.30812/humanitatis.v8i1.1284 


\section{RESEARCH METHOD}

This The data taken for this study are from scenes of a TV series entitled "Chernobyl" in the form of monologue and dialogue that the character had spoken orally and will be transcribed manually. Chernobyl is a drama produced by HBO and Sky UK after a nuclear plant disaster history which was occurred in April 1986 in the Ukrainian Soviet Socialist Republic. This is a historical drama produced in 2019 with Craig Mazin as the script writer and directed by Johan Renck. The series first premiered on May 6, 2019 in the United States and won for the Best Miniseries or Television at the 77th Golden Globe Awards. This TV series is chosen because the psychoanalysis of the main character as well as the conflicts experienced by the character fulfilled the data that is needed for this study.

The data for this study collected from each of Chernobyl episodes in the TV series by using the technique of observation to get the idea of the human behaviors. However, note taking technique is used in order to write important information found in the series to get more output that is beneficial when analyzing the data. The collected data then are identified based on the kinds of conflicts experienced by the main character according to theory of conflict by Kenney (1966) and also based on the psychological aspects found in the main character, according to theory of psychoanalysis by Freud (1923).

The collected data are analyzed by using qualitative method and focused on developing meaning and also ideas from the series. In analyzing the data, content analysis as the technique is used because the data source is a form of media (video). The method used to analyze the data in this study is qualitative method, hence, the informal method is used in presenting the result of the analysis. Informal method is used to present the data with words and sentences that give clear explanation and make the readers understand easily.

\section{FINDINGS AND DISCUSSION}

The analysis in this study is done by applying two theories which are concerned about the conflict and the psychological aspect of the main character. The theories used are theory of conflict by Kenney (1966) that focused on the internal and external conflict experienced by Valery Legasov as the main character, and followed by theory of psychoanalysis by Freud (1923) that focused on analyzing the mind and behavior the main character possessed. Based on the theory of psychoanalysis, the three parts of human personality that are divided into the id, ego, and superego are analyzed to get the idea which psychological aspect he used in handling conflicts he experienced in the story.

Online at https://journal.universitasbumigora.ac.id/index.php/humanitatis/

DOI : https://doi.org/10.30812/humanitatis.v8i1.1284 


\section{Data 1}

\section{Episode 2}

Shcherbina : (to the pilot) "Get us directly over the building!"

Legasov : "Boris, if we fly..."

Shcherbina : "Don't you use my name!"

Legasov $\quad$ : “...directly over an open reactor, we'll be dead within a week! Dead!

Context:

Gorbachev (the chairman of the government commission in Soviet Union), assigned Shcherbina to go to Chernobyl and lead the commission of the Chernobyl disaster right away along with Legasov As the helicopter started approaching the power plant, Legasov turned his head toward the window and he saw the faint blue smoke flowing outside the reactor. From the centre of the building, it looked like the fire was pouring out. The core was blown open and the radiation was surely exposed as he saw the graphite scattered all over the roof. Shcherbina was in shock to understand what happened. Therefore, he wanted to get close to that exploded power plant in order to get a better look. He then ordered the pilot to get them there. However, Legasov immediately objected to Shcherbina's request. It was too risky for them to get close to the plant because of the radiation spreading in the air. This made them argue.

Their arguments appeared to be an external conflict where Legasov also lost his temper and shouted at Shcherbina because he insisted to fly over the reactor, in fact, it would be dangerous. Legasov objected Shcherbina's request, yelled at him and said, "We'll be dead within a week! Dead!" Legasov told Shcherbina that if they flew over there, they would all be dead in a week because of the radiation that got through them. The psychological aspect that was dominant in Legasov at that time is the id. In order to prevent them from getting close to the building, the id was taking control. And the need to fulfil the id, the ego executed it by letting Legasov yell at Shcherbina so that the helicopter would stay away from the building.

\section{Data 2}

\section{Episode 3}

Legasov : "Comrade Charkov."

(Charkov turns around)

Charkov : "Yes, Professor?"

Online at https://journal.universitasbumigora.ac.id/index.php/humanitatis/

DOI : https://doi.org/10.30812/humanitatis.v8i1.1284 
Legasov : :My associate was arrested last night."

Charkov : "Oh?"

Legasov : "I mean no disrespect, but I was wondering if you could tell me why."

Charkov : :I'm sorry. I don't know who you're talking about."

Legasov : "She was arrested by the KGB. You are First Deputy Chairman of the KGB."

Context:

Khomyuk is in the Moscow Hospital. There, she questioned all of the hospitalized engineers who worked in the plant and asked several questions that related to the disaster. Unfortunately, Khomyuk got arrested by the KGB when she tried to interview the hospitalized workers. Legasov who heard about Khomyuk getting arrested immediately went to meet the KGB minister Charkov.

From the data number 2, the way Legasov said, "My associate was arrested last night," showed that Legasov was upset. He could not hold his anger and it directed him to provoke Charkov. The external conflict Legasov and Charkov had showed that they both have different goals to achieve. Legasov wanted Khomyuk to investigate the cause of Chernobyl, however, Charkov ended up arresting Khomyuk because Charkov planned to keep the truth about Chernobyl in secret. The moment Legasov wanted to reach Charkov in a hurry showed that it was his id which took control because the id worked based on instinct and did not know morals. Then the ego executed what the id wanted where it can be seen from the way Legasov walked fast toward Charkov and hurriedly approached him to talk about Khomyuk's arrest.

\section{Data 3}

\section{Episode 5}

Charkov : : "You're one of us, Legasov. You've always been one of us. I can do anything I want with you. But what I want the most is for you to know that I know. You're not brave. You're not heroic. You're just a dying man who forgot himself."

Legasov : :I know who I am, and I know what I've done. In a just world, I'd be shot for my lies. But not for this. Not for the truth."

Charkov : "Scientists... and your idiot obsession with reasons. When the bullet hits your skull, what will it matter why?"

Online at https://journal.universitasbumigora.ac.id/index.php/humanitatis/

DOI : https://doi.org/10.30812/humanitatis.v8i1.1284 


\section{Context:}

Legasov insisted on declaring all the truth behind what happened in Chernobyl in the trial. He also mentioned that the intervention of the KGB made him cover most of the facts that existed. The KGB was also hiding other facts that other reactors which are still running have the same errors like reactor 4 in Chernobyl. Even after Legasov already revealed the true information about the causes of the accident, the judge still did not believe what Legasov said and accused him for insulting the nation. With so much effort Legasov put to convince the judge, it was not enough. Later on, Legasov was guided by a soldier and left the trial to an abandoned room. Shortly after, the door opened and the Chief Deputy of KGB, Charkov, entered the room. He threatened Legasov. For what Legasov did in the trial, Charkov was displeased and said something terrible. He degraded Legasov by saying that Legasov is only a dying man.

Legasov resisted and defended himself from the threat. He believed in what he had done. He believed that the truth should be told to the world even though he knew he would receive a shot. This kind of conflict described that they have different goals, which each one of them have their own way to protect his country that made them opposed each other. The psychological aspect that controlled Legasov's mind and behaviour was his superego. He could think and talk in a reasonable way to defend himself (ego) when Charkov intimidated him. The ego could act according to the moral principle of superego, even though he stood in a stressful situation.

\section{Data 4}

\section{Episode 5}

Charkov : "What role did Shcherbina play in this?"

Legasov : "None. He didn't know what I was going to say."

Charkov : "What role did Khomyuk play in this?"

Legasov : "None. She didn't know either."

Charkov : "After all you've said and done today, it would be curious if you chose this moment to lie."

Legasov : "I would think a man of your experience would know a lie when he hears one."

Charkov : "You will not meet or communicate with either one of them ever again. You

will not communicate with anyone about Chernobyl ever again. You will remain

so immaterial to the world around you that when you finally do die, it will be

exceedingly hard to tell that you ever lived at all."

Online at https://journal.universitasbumigora.ac.id/index.php/humanitatis/

DOI : https://doi.org/10.30812/humanitatis.v8i1.1284 


\section{Context:}

Charkov who was always being a cautious person asked whether Shcherbina and Khomyuk were involved or not. The truth was, Shcherbina and Khomyuk did cooperate with Legasov even though they were only supporting him from behind. But at the end, Legasov protected Shcherbina and Khomyuk and did not want them to get caught by the KGB by lying about their alliance.

The tense atmosphere around Legasov and Charkov when they conversed indicated that it was a conflict happened since each one of them has different goals to achieve. Charkov wanted to dig more information about Chernobyl to Legasov in order to keep the truth buried down, however, Legasov decided to cover up his colleagues so his colleagues would not get arrested for helping him. The data number 4 above showed that the way Legasov tried to keep his friends safe was controlled by superego because superego works under ideal judgment. The ego performed it by deceiving Charkov and it was a success since Charkov assumed that Shcherbina and Khomyuk were not involved. Charkov decided to put Legasov under an ordinance alone but not with Shcherbina and Khomyuk.

\section{CONCLUSION}

In the series Chernobyl, Legasov as the main character mainly encountered conflicts that occurred from the outside, specifically conflicts that happened with other characters. The conflict that happened most often were different opinions and different goals with Shcherbina as well as Charkov that related with the disaster that happened in the story.

From the psychoanalysis, the conflicts which are handled by the main character are divided by the id, ego, and superego. The link between psychological aspects with conflict is closely related, thus, it made a great influence especially when it comes to making judgment in dealing with conflicts. Based on the data gathered, all of the data contain the aspect of ego because ego mediates between the id and superego and it acts according to which of those two aspects that have strong will. Ego appears the most in regards of handling the conflict, followed with superego, and the id is at least. This shows that even though Legasov often faced difficult or depressing situations, he could think rationally and morally, rather than making judgment impulsively based on his instinct.

Online at https://journal.universitasbumigora.ac.id/index.php/humanitatis/

DOI : https://doi.org/10.30812/humanitatis.v8i1.1284 


\section{REFERENCES}

Creswell, J. W. (2014). Research Design: Qualitative, Quantitative, and Mixed Method Approaches. Washington DC: SAGE.

Freud, S. (1923). The Ego and the Id. The Standard Edition of the Complete Psychological Works of Sigmund Freud Volume XIX. Vienna: W. W. Norton \& Company.

Kenney, W. (1966). How to analyze fiction: A critical guide to appreciation of short stories, novellas, and novels. New York: Monarch Press.

Nurgiyantoro, B. (1995). Teori Pengkajian Fiksi Yogyakarta: Gadjah Mada University Press.

Orvis, M. B. (1948). The Art of Writing Fiction. New Jersey: Prentice-Hall.

Reaske, C. R. (1984). How to Analyze Drama. New York: Monarch Press.

Taylor, R. (1981). Understanding the Elements of Literature. London: Macmillan Education.

Wellek, R., \& Warren, A. (1942). Theory of Literature. Brace New York: Hartcourt.

Online at https://journal.universitasbumigora.ac.id/index.php/humanitatis/

DOI : https://doi.org/10.30812/humanitatis.v8i1.1284 
Online at https://journal.universitasbumigora.ac.id/index.php/humanitatis/

DOI : https://doi.org/10.30812/humanitatis.v8i1.1284 